EMPOWER : Jurnal Pengembangan Masyarakat Islam

Vol. 5, No.1, Juni 2020, hlm. 101-117

e-ISSN : 2580-0973, p-ISSN : 2580-085X

Tersedia Online di : http://syekhnurjati.ac.id/jurnal/index.php/empower

Email : empowerjurnal@gmail.com

\title{
Menghidupkan Kembali Gagasan Ekonomi Koperasi sebagai Fondasi Perekonomian Nasional
}

\author{
Hamdan Hamdani \\ (Prodi Pengembangan Masyarakat Islam, Fakultas \\ Ushuluddin Adab dan Dakwah, IAIN Syekh Nurjati \\ Cirebon) \\ hamdanhamdani001@gmail.com \\ Article History \\ Submitted: 05.04.2020; Revised: 14.06.2020; Accepted: 21.06.2020;
}

\begin{abstract}
This research is motivated by the author's interest in studying the economic ideas of cooperatives contained in Article 18 of the 1945 Constitution. Cooperatives as a joint venture is able to reflect the provisions as in family life. In a family, everything that is done together is aimed at the common interests of all family members. Cooperatives are established and built to create an economic system that guarantees more equitable distribution so that economic control is not concentrated in a group of people. So that everyone can achieve prosperity through joint efforts. The purpose of this study is to find out how the economic ideas of cooperatives can be used as a foundation of the national economy. The research method used in this research is the literature study research method. The conclusion of this research states that cooperatives have the characteristics of economic democracy, which is economic activities are regulated by the people, carried out by the people, and aimed at people's welfare. Therefore, if the cooperatives economic system is implemented in a consistent and sustainable, it is not impossible that the economic problems which still hold the Indonesian people will gradually be overcome.
\end{abstract}

Keywords: Cooperatives, Article 33 of the 1945 Constitution, The National Economy

\section{Abstrak}


Penelitian ini dilatarbelakangi oleh ketertarikan penulis dalam mengkaji gagasan ekonomi koperasi yang terkandung dalam UUD 1945. Koperasi sebagai suatu usaha bersama mampu mencerminkan ketentuan-ketentuan sebagaimana dalam kehidupan berkeluarga. Dalam suatu keluarga, segala sesuatu yang dikerjakan secara bersama-sama ditujukan untuk kepentingan bersama seluruh anggota keluarga. Koperasi didirikan dan dibangun untuk menciptakan sistem ekonomi yang lebih menjamin adanya pemerataan yang lebih adil sehingga penguasaan ekonomi tidak terkonsentrasi pada sekelompok orang saja, sehingga setiap orang bisa mencapai kesejahteraan lewat usaha yang dilakukan secara bersama-sama. Tujuan penelitian ini adalah untuk mengetahui bagaimana gagasan ekonomi koperasi dapat dijadikan sebagai fondasi perekonomian nasional. Metode penelitian yang digunakan pada penelitian ini adalah menggunakan metode penelitian studi pustaka. Kesimpulan dari penelitian ini menyatakan bahwa koperasi memiliki karakteristik demokrasi ekonomi, dimana kegiatan ekonomi diatur oleh rakyat, dilaksanakan oleh rakyat, dan ditujukan untuk kesejahteraan rakyat. Oleh karena itu, apabila sistem ekonomi koperasi diterapkan secara konsisten dan berkelanjutan, tidak mustahil permasalahan ekonomi yang sampai saat ini masih membelenggu bangsa Indonesia, secara perlahan-lahan akan dapat teratasi.

Kata kunci: Koperasi, Pasal 33 UUD 1945, Perekonomian Nasional.

\section{PENDAHULUAN}

Diawali dari pertanyaan apakah sebenarnya sistem ekonomi yang dianut Indonesia? apakah sistem ekonomi sosialis? apakah sistem ekonomi kapitalis? ataukah campuran dari keduanya? Sebenarnya jika kita melihat realitas yang terjadi pada bangsa Indonesia, apapun sistem ekonomi yang dianut Indonesia, nyatanya sampai saat ini perekonomian Indonesia masih terpuruk. Perekonomian Indonesia juga dirasakan belum sepenuhnya prorakyat, hal tersebut dilandasi dari kenyataan bahwa pembangunan nasional masih belum merata dinikmati oleh seluruh lapisan masyarakat, sehingga ketimpangan antara antara 'si kaya' dan 'si miskin' masih banyak terjadi. 
Dalam sejarah perjuangan kemerdekaan bangsa Indonesia, sesungguhnya para Founding Father telah meletakan pondasi awal sistem perekonomian Indonesia yang termaktub dalam UUD 1945. Tentu saja, proses perumusan sistem ekonomi Indonesia yang dilakukan oleh Bung Hatta dan tokoh bangsa lainnya setelah mereka mempelajari sistem perekonomian yang berkembang di dunia saat itu.

Dalam UUD 1945 terutama pasal 33, secara eksplisit dijelaskan bahwa roda perekonomian Indonesia harus dijalankan menggunakan sistem perekonomian kekeluargaan yang menjadi core value dalam sistem ekonomi koperasi, hanya saja sayangnya pemerintah Indonesia belum konsisten dalam melaksanakan amanat negara tersebut. Barangkali hal inilah salah satu penyebab bangsa Indonesia masih terpuruk secara perekonomian sampai saat ini.

Jika kita bicara tentang permasalahan ekonomi bangsa Indonesia, kiranya perlu kita ingat kembali masalah dasar ekonomi yang dihadapi oleh setiap bangsa. Pada hakikatnya, masalah ekonomi bersumber dari adanya ketidakseimbangan antara kebutuhan manusia dengan ketersediaan komoditi kebutuhan. Ketidakseimbangan tersebut menyebabkan terjadinya kelangkaan komoditi kebutuhan, dan pada akhirnya menyebabkan munculnya masalah ekonomi.

Selain masalah dasar ekonomi, kita juga mengenal masalah umum ekonomi yang dihadapi oleh bangsa Indonesia. Masalah umum ekonomi itu meliputi masalah pengangguran, rendahnya produktivitas tenaga kerja, inflasi, ketidakmerataan hasil pembangunan, rendahnya pertumbuhan ekonomi, kemiskinan, dan ketergantungan terhadap pihak luar negeri.

Solusi untuk memecahkan masalah perekonomian bangsa Indonesia tersebut sedikit banyak tentu dipengaruhi oleh sistem ekonomi yang dianut oleh negara Indonesia. Dalam Pasal 33 UUD 1945, Indonesia menggunakan sistem ekonomi yang dikenal dengan sistem demokrasi ekonomi ${ }^{1}$. Sistem demokrasi ekonomi dapat diartikan sebagai suatu sistem ekonomi dimana kegiatan ekonomi diatur oleh rakyat, dilaksanakan oleh rakyat, dan

\footnotetext{
${ }^{1}$ Dawam Raharjo, Koperasi Indonesia Menghadapi Abad Ke-21 (Jakarta: DEKOPIN, 1997). p. xii.
} 
ditujukan untuk kesejahteraan rakyat. Di dalam sistem demokrasi ekonomi ini, segala produksi yang menguasai hajat hidup orang banyak dikuasai oleh negara, sedangkan produksi yang lainnya diserahkan pada pasar. Terhadap produksi yang lain ini pemerintah hanya berperan sebagai pengawas pasar saja.

Dalam pasal 33 UUD 1945, sistem demokrasi ekonomi dijabarkan secara jelas bahwa pengelolaan kegiatan ekonomi harus dilaksanakan secara kekeluargaan. Bentuk badan ekonomi yang paling cocok dengan sistem demokrasi ekonomi ini adalah koperasi. Oleh karena itu, koperasi harus menjadi fondasi perekonomian, artinya koperasi diposisikan sebagai landasan utama bagi seluruh kebijakan perekonomian nasional.

Koperasi perlu dibangun atas prinsip-prinsip dan jati diri yang dimilikinya, sehingga koperasi dapat berkembang, maju dan mandiri serta mampu berperan sebagai fondasi perekonomian nasional. Konsistensi pelaksanaan gagasan ekonomi koperasi sebagai soko guru perekonomian nasional menjadi sangat menarik untuk dikaji. Oleh karena itu, penulis tertarik untuk menulis penelitian dengan judul "Menghidupkan Kembali Gagasan Ekonomi Koperasi sebagai Fondasi Perekonomian Nasional". Agar penelitian ini lebih terarah pada sasaran yang diinginkan dengan benar dan tepat, maka penulis memfokuskan pembahasan penelitian ini pada gagasan ekonomi koperasi yang terkandung dalam amanat UUD 1945. Adapun yang menjadi perumusan masalah dalam penelitian ini adalah bagaimana menghidupkan kembali gagasan ekonomi koperasi sebagai fondasi perekonomian nasional? Sedangkan yang menjadi tujuan penelitian ini adalah untuk mengetahui gagasan ekonomi koperasi sebagai soko guru perekonomian nasional.

Metode penelitian yang digunakan pada penelitian ini adalah menggunakan metode penelitian studi pustaka. Studi kepustakaan adalah kegiatan untuk menghimpun informasi yang relevan dengan topik atau masalah yang menjadi obyek penelitian. Informasi tersebut dapat diperoleh dari buku, ensiklopedia, internet, karya ilmiah, tesis, disertasi, dan sumbersumber lainnya. Oleh karena itu dalam studi kepustakaan, data didominasi oleh pengumpulan data non-lapangan sekaligus meliputi objek yang diteliti dan data yang digunakan untuk membicarakannya, sebagai objek primer 
sekaligus sekunder ${ }^{2}$. Dengan melakukan studi kepustakaan, peneliti dapat memanfaatkan semua informasi dan pemikiran-pemikiran yang relevan dengan penelitian yang sedang dilakukan.

\section{HASIL DAN PEMBAHASAN}

\section{Perekonomian Nasional}

Setiap negara pasti memiliki sistem perekonomiannya masingmasing. Sistem perekonomian tersebut merupakan sekumpulan komponenkomponen yang terdiri atas unit-unit serta lembaga-lembaga ekonomi suatu negara yang saling berhubungan dalam mekanisme pengambilan kebijakan terkait produksi, distribusi, konsumsi sekaligus pengaturan pendapatan dan pengeluaran belanja negara ${ }^{3}$. Untuk menyejahterakan rakyatnya, setiap negara berhak menentukan sendiri sistem perekonomiannya masing-masing, namun negara harus tetap menaati aturan main berekonomi yang bersumber pada prinsip-prinsip etika dan ideologi yang telah diwariskan para pendiri bangsanya ${ }^{4}$.

Jika menilik kembali sejarah, sistem perekonomian Indonesia awal mulanya banyak dipengaruhi oleh sistem perekonomian Belanda, yang telah berkuasa atas ekonomi Indonesia sekitar 350 tahun, lewat organisasi ekonomi yang dibentuknya (VOC) dan pelaksanaan sistem tanam paksa (cultuur stelsel).

Pasca kemerdekaan Indonesia, para pendiri bangsa berusaha membangun kembali fondasi sistem perekonomian Indonesia yang dianggap ideal sesuai dengan kondisi bangsa. Bung Hatta mencetuskan sebuah kerangka konsep tentang sistem perekonomian Indonesia yang disebut sistem ekonomi kerakyatan. Dalam sistem ekonomi kerakyatan, semua aktivitas ekonomi harus berdasarkan asas kekeluargaan, gotong royong dan usaha bersama dikalangan rakyat. Konsep sistem ekonomi

\footnotetext{
${ }^{2}$ Andi Prastowo, Metode Penelitian Kualitatif (Jakarta: Ar-Ruzz Media, 2016), p. 191. ${ }^{3}$ Pratama Rahardja, Pengantar Ilmu Ekonomi (Jakarta: Lembaga Penerbit FE UI, 2008), p. 464.

${ }^{4}$ Dkk Soeharsono Sagir, Kapita Selekta Ekonomi Indonesia (Jakarta: Kencana, 2009), pp. 438-439.
} 
kerakyatan inilah yang kemudian dituangkan dalam Pasal 33 UUD 1945 sebagai dasar sistem perekonomian nasional.

Konsep sistem ekonomi kerakyatan mustahil dapat tercapai secara instant dalam waktu yang singkat, karena itu hal yang paling utama dilakukan dalam hal ini yaitu semua program atau aktivitas perekonomian bangsa harus diarahkan sedemikian rupa sesuai dengan konstitusi negara yaitu Pasal 33 UUD 1945 sehingga proses pengejawantahan kehidupan perekonomian bangsa tidak melenceng dari amanat konstitusi tersebut.

Arah kebijakan perekonomian nasional harus memprioritaskan terwujudnya rakyat yang adil, makmur dan sejahtera. Apabila pelaksanaan kebijakan perekonomian tidak mencerminkan kesejahteraan dan keadilan sosial untuk seluruh rakyat, maka tentu hal tersebut akan mengakibatkan kesengsaraan dan penderitaan bagi rakyat. Keadaan tersebut justru pada akhirnya bisa menjadi penyebab terciptanya konflik dan perpecahan antar anak bangsa.

Para pendiri bangsa sudah meletakan fondasi perekonomian nasional yang begitu hebat lewat Pasal 33 UUD 1945. Tinggal bagaimana saat ini para penerus bangsa terutama pemerintah yang berkuasa untuk menjalankannya dengan konsisten dan sungguh-sungguh. Political will dalam menjalankan perekonomian yang pro-rakyat tersebut menjadi penting untuk menciptakan kemakmuran seluruh rakyat Indonesia.

\section{Pemaknaan Pasal 33 UUD 1945}

Pasal 33 Undang Undang Dasar 1945 merupakan amanat konstitusi dalam bidang kehidupan ekonomi. Pasal ini mengandung pesan yang begitu mendalam, selain sebagai pedoman terkait wewenang negara dalam mengatur kegiatan perekonomian, pasal ini juga mengandung cita-cita dan keyakinan yang harus dipegang teguh serta diperjuangkan oleh para pimpinan pemerintahan selanjutnya ${ }^{5}$.

Pada awalnya hanya terdapat tiga ayat dalam Pasal 33 UUD 1945. Setelah amandemen Undang Undang Dasar 1945 keempat pada tanggal 10 Agustus 2002, Pasal ini ditambah dengan memasukkan 2 (dua) ayat baru,

\footnotetext{
${ }^{5}$ Bagir Manan, Pertumbuhan Dan Perkembangan Konstitusi Suatu Negara (Bandung: Mandar Maju, 1995), p. 45.
} 
yaitu Ayat (3) dan (4) ${ }^{6}$. Pada paragraf di bawah ini, penulis akan mencoba memberikan deskripsi singkat pemaknaan Pasal 33 UUD 1945 dalam setiap ayat yang terkandung di dalamnya.

Pasal 33 ayat (1) Undang Undang Dasar 1945 menegaskan, bahwa: "Perekonomian disusun sebagai usaha bersama berdasarkan atas asas kekeluargaan". Pemaknaan usaha bersama berasas kekeluargaan tersebut merupakan simbol yang menyatakan suatu hubungan yang saling menguntungkan (mutualisme). Dalam konteks ajaran agama Islam, mutualisme mengandung arti berjamaah atau ber-ukhuwah ${ }^{7}$. Itulah sebabnya, sesuai paham mutualisme, kepentingan publik (public-interest) menjadi prioritas utama.

Sebagai penegasan posisi rakyat sebagai sesuatu yang sentralsubstansial, maka disusunlah ayat (2) Pasal 33 Undang-Undang Dasar 1945, bahwa: "Cabang-cabang produksi yang penting bagi negara dan yang menguasai hajat hidup orang banyak dikuasai oleh negara". Pemaknaan kata "dikuasai negara" dalam ini tidak lantas diartikan bahwa negara sebagai pelaku usaha yang mengurusi semuanya seorang diri, karena jika itu yang dilakukan pasti negara sangat membutuhkan modal pengelolaan yang sangat tinggi, SDM yang mumpuni dan penguasaan teknologi canggih. Penulis justru memaknai kata "dikuasai oleh negara" ini memiliki arti bahwa negara memiliki kewenangan penuh untuk mengatur dan mengawasi mekanisme pengelolaan aset perekonomian negara tersebut dengan berbagai pihak tanpa mengesampingkan tujuan utamanya yaitu menyejahterakan rakyat dan memastikan tidak terjadinya monopoli atau penindasan oleh sekelompok orang yang memiliki modal lebih terhadap rakyat lemah.

Pasal 33 Ayat (3) UUD 1945 menyatakan: "Bumi dan air dan kekayaan alam yang terkandung di dalamnya dikuasai oleh negara dan dipergunakan untuk sebesar-besar kemakmuran rakyat". Ayat ini menekankan pentingnya pemaknaan bahwa bangsa Indonesia memegang

\footnotetext{
${ }^{6}$ D Soekarno, Amandemen Terhadap UUD 1945 (Jakarta: Suara Pembaharuan, 2006), p. 1.

${ }^{7}$ Sri Edi Swasono, Tentang Demokrasi Ekonomi Indonesia (Jakarta: Bappenas, 2008), p. 3.
} 
kuasa penuh atas segala kekayaan alam yang terkandung dalam bumi dan air yang ada di seluruh wilayah Indonesia. Ayat ini juga memberikan amanat kepada negara untuk mengelola dan memanfaatkan kekayaan alam tersebut sebaik-baiknya untuk menciptakan rakyat yang adil dan makmur.

Pasal 33 ayat (4) UUD 1945 menjelaskan bahwa: "Perekonomian nasional diselenggarakan berdasar atas demokrasi ekonomi dengan prinsip kebersamaan, efesiensi berkeadilan, berkelanjutan, berwawasan lingkungan, kemandirian, serta dengan menjaga keseimbangan kemajuan dan kesatuan ekonomi nasional". Pernyataan dalam ayat ini memberikan pesan tersurat terkait demokrasi ekonomi. Pemaknaan demokrasi ekonomi Indonesia tersebut sebagai bentuk usaha untuk mewujudkan keadilan sosial bagi seluruh rakyat Indonesia, sehingga negara memiliki tanggung jawab untuk melakukan perlindungan bagi rakyat yang memiliki keterbatasan dan keterbelakangan dalam aspek ekonomi dan sosial. Perlindungan ini bukanlah sikap yang membeda-bedakan apalagi mendiskriminasi, melainkan memberikan penguatan akan makna positif terkait asas kebersamaan dan kekeluargaan untuk seluruh rakyat Indonesia. Sedangkan Pasal 33 ayat (5) UUD 1945 berbunyi bahwa: "Ketentuan lebih lanjut mengenai pelaksanaan pasal ini diatur dalam undang-undang".

Semua ayat dalam Pasal 33 UUD 1945 tersebut harus dibaca sebagai satu kesatuan yang utuh, sehingga secara keseluruhan Pasal 33 UUD 1945 dapat dipahami sebagai fondasi utama dalam sistem perekonomian nasional bangsa Indonesia, dimana pembebasan kehidupan rakyat dari diskriminasi, kebodohan, kemiskinan dan ketergantungan merupakan sebuah tujuan yang ingin dicapai dalam sistem ekonomi yang berbasis kerakyatan ini.

\section{Konsep Koperasi}

Koperasi secara etimologi berasal dari bahasa Inggris yaitu 'cooperatives' yang berarti kerjasama ${ }^{8}$. Sedangkan koperasi menurut Syafi'I

\footnotetext{
${ }^{8}$ Muhammad Firdaus, Perkoperasian: Sejarah, Teori Dan Praktek (Bogor: Ghalia Indonesia, 2004), p. 23-24.
} 
Jafri dalam bukunya Fiqih Muamalah adalah 'As-Syirkah' menurut bahasa ialah 'ikhtilah' (percampuran), sedangkan menurut syara' diartikan dengan akad antara orang-orang yang berkongsi (berserikat) dalam hal modal dan keuntungan'.

Dalam Kamus Belanda-Indonesia disebut dengan istilah 'coöperatie' yang berarti bekerjasama ${ }^{10}$. Lalu, dalam Kamus Bahasa Indonesia, koperasi merupakan perserikatan yang bertujuan memenuhi keperluan kebendaan paraanggotanya dengan cara menjualbarang-barang kebutuhan denganharga murah ${ }^{11}$.

Chaniago memberi definisi koperasi sebagai suatu perkumpulan yang beranggotakan orang-orang atau badan hukum yang memberikebebasan masuk dan keluar sebagai anggota dengan bekerja sama secara kekeluargaan danmenjalankan usaha untuk mempertinggi kesejahteraan para anggotanya ${ }^{12}$.

Dari beberapa pendapat para ahli di atas mengenai koperasi, maka secara garis besar dapat disimpulkan bahwa koperasi merupakan perkumpulan dari orang-orang secara sukarela dengan tujuan untukmeningkatkan kesejahteraan bersama.

\section{Sejarah Perkembangan Koperasi}

Jika menilik secara historis, sebenarnya koperasi bukanlah lembaga atau sistem ekonomi yang khas berasal dari Indonesia. Sebab pada abad pertengahan, di Eropa tepatnya di negara Inggris, kegiatan berkoperasi sudah mulai dikenal. Pada mulanya tujuan utama berkoperasi saat itu yaitu untuk membantu kaum petani dan kelas pekerja dalam menghadapi permasalahan ekonomi dengan menggalang kekuatan mereka sendiri ${ }^{13}$.

\footnotetext{
${ }^{9}$ Syafi'I Jafri, Fiqih Muamalah (Pekanbaru: Susqa Press, 2002), p. 88.

10 Moeimam Dkk, Kamus Belanda-Indonesia (Jakarta: Gramedia Pustaka Utama, 2008), p. 208

${ }^{11}$ Departemen Pendidikan Nasional, Kamus Besar Bahasa Indonesia (Jakarta: Pusat Bahasa, 2008), p. 753

${ }^{12}$ Rustam Efendi and Boy Syansul Bakhri, 'Konsep Koperasi Bung Hatta Dalam Perspektif Ekonomi Syariah', Al-Hikmah: Jurnal Agama Dan Ilmu Pengetahuan, 15.1 (2018), 111-35,p. 114.

${ }^{13}$ Camelia Fanny Sitepu and Hasyim Hasyim, 'Perkembangan Ekonomi Koperasi Di Indonesia', NIAGAWAN, 7.2 (2018), p. 62.
} 
Selain di Inggris, kegiatan berkoperasi juga sudah dikenal di Perancis pada abad ke 19. Latar belakang berkoperasi saat itu yaitu merupakan salah satu gerakan perlawanan kaum buruh yang tertindas oleh kekuatan kapitalis. Semangat yang diusung saat itu yaitu untuk menciptakan suatu ekonomi alternatif dari asosiasi-asosiasi koperasi untuk menggantikan perusahaan-perusahaan milik kapitalis. Pada perkembangan selanjutnya ide koperasi ini kemudian menjalar ke Amerika dan negaranegara lainnya di dunia ${ }^{14}$.

Sebagaimana sejarah lahirnya koperasi di Eropa yang merupakan bentuk gerakan perlawanan kaum buruh dan petani terhadap perusahaanperusahaan kapitalis, Di Indonesia pun konteks lahirnya koperasi merupakan salah satu usaha memperbaiki perekonomian rakyat yang ditindas oleh penjajahan pada masa itu.

Dalam catatan literatur, koperasi di Indonesia pada awal mulanya lahir pada tahun 1896 dipelopori seorang patih dariPurwokerto yang bernama R. Aria Wiriaatmadja. Patih R. Aria Wiriaatmadja saat itu mendirikan sebuah koperasi simpan-pinjam dengan modal awal berasal dari dirinya sendiri. Pada saat itu tujuan Patih R. Aria Wiriaatmadja mendirikan koperasi simpan-pinjam yaitu untuk membantu para rakyat yang terlilit hutang.

Selanjutnya pada tahun 1908, Budi Utomo, sebuah organisasi yang bergerak di bidang pendidikan juga ikut membantu memperbaiki kesejahteraan rakyat melalui pendirian koperasi rumah tangga, yang dipelopori oleh Gunawan Mangunkusumo.

Lalu pada tahun 1911, Serikat Dagang Islam (SDI) yang dipimpin oleh H. Samanhudi dan H.O.S Cokroaminoto mengembangkan koperasikonsumsi untuk memenuhi kebutuhan rumah tangga dengan caramembuka toko-toko koperasi (sejenis warung serba ada), pendirian koperasi tersebut bertujuan untuk mengimbangi dan menentang politik pemerintah kolonial belanda yang banyak memberikan fasilitas dan menguntungkan para pedagang asing ${ }^{15}$.

\footnotetext{
${ }^{14}$ Hendar, Manajemen Perusahaan Koperasi (Jakarta: Erlangga, 2010), pp. 6-7.

${ }^{15}$ Hendar.
} 
Namun sayang dalam perkembangannya, baik koperasi yang dibentuk oleh Budi Utomo maupun Serikat Dagang Islam, keduanya 'layu sebelum berkembang', artinya walaupun memiliki cita-cita awal yang mulia namun pada kenyataannya koperasi-koperasi yang didirikan tersebut belum berhasil membantu perekonomian masyarakat pada saat itu. Banyak hal yang menyebabkan kegagalan pelaksanaan koperasi saat itu, diantaranya disebabkan oleh belum adanya pengalaman dalam pengelolaan unit usaha, kurangnya minat masyarakat untuk terlibat dalam kegiatan koperasi dan lemahnya pengetahuan perkoperasian para pengurus koperasi saat itu.

Dr. Soetomo pada tahun 1927 mendirikan Indonesische Studieclub di Surabaya dan melalui organisasi tersebut beliau menganjurkan berdirinya koperasi. Kegiatan serupa juga dilakukan Ir. Soekarno lewat kongres koperasi Partai Nasional Indonesiadi Betawipada tahun 1929. Keputusan kongres tersebut menyatakan bahwa untuk meningkatkan kemakmuran penduduk bumi putera, harus didirikan berbagai macam koperasi di seluruh pulau Jawa khususnya dan Indonesia pada umumnya.

Setelah proklamasi kemerdekaan Indonesia, dengan tegas perkoperasian ditulis di dalam UUD 1945. Dalam Pasal 33 UUD 1945 ayat 1 dijelaskan bahwa perekonomian disusun sebagai usaha bersama berdasarkan asas kekeluargaan. Dalam penjelasan UUD tersebut, disampaikan bahwa bangun perekonomian yang sesuai dengan asas kekeluargaan tersebut adalah koperasi ${ }^{16}$.

\section{Menghidupkan Kembali Gagasan Ekonomi Koperasi sebagai Soko Guru Perekonomian Nasional}

Gagasan ekonomi koperasi diharapkan kembali menjadi fondasi perekonomian nasional. Namun, kenyataannya perlu ekstra kerja keras agar cita-cita tersebut menjadi suatu keniscayaan, padahal usia koperasi yang hampir mencapai 73 tahun pada 12 Juli 2020 nanti. Hal tersebut berdasar pada masih rendahnya kontribusi koperasi terhadap PDB, masih jauh tertinggal dibandingkan dengan negara-negara lain di dunia. Sebagai

\footnotetext{
${ }^{16}$ Hendar.
} 
contoh, Kenya sebuah negara di Afrika yang relatif miskin, koperasi berkontribusi terhadap PDB negaranya mencapai 43 persen. Bahkan di negara Denmark, koperasi dapat berkontribusi sebesar 68 persen dari PDB. Sebaliknya, di Indonesia, pada tahun 2017, kontribusi koperasi hanya mampu mencapai angka 4,9 persen dari $\mathrm{PDB}^{17}$. Lantas, bagaimana upaya yang harus dilakukan agar koperasi bangkit kembali menjadi fondasi perekonomian nasional? Pada paragraf selanjutnya, penulis akan mencoba menjawab pertanyaan tersebut ke dalam sebuah uraian deskriptif.

Dalam banyak literatur yang telah penulis baca, koperasi selain menjadi wadah perekonomian, dapat juga dijadikan sebagai lokomotif untuk pendidikan moril masyarakat. Hal tersebut dikarenakan koperasi mengandung dua sendi yang saling memperkuat, yaitu sendi kolektifitas (solidaritas) sekaligus sendi individualitas (kesadaran akan harga diri sendiri). Dua sendi itu akan bertambah kuat karena dipupuk dalam koperasi, kolektifitas dan individualitas akan berjalan beriringan dalam hubungan yang harmonis sesuai asas koperasi berdasarkan UU Perkoperasian No. 25 tahun 1992.

Menurut UU No. 25 Tahun 1992, koperasi merupakan badan usaha yang beranggotakan orang-seorang atau badan hukum dengan melandaskan kegiatannya berdasarkan prinsip koperasi, sekaligus sebagai gerakan ekonomi rakyat yang berdasar atas asas kekeluargaan ${ }^{18}$. Dalam literatur koperasi lainnya, ditemukan banyak keterangan bahwa koperasi harus memiliki prinsip dan nilai-nilai yang berfungsi sebagai pedoman bagi kegiatan perkoperasian. Serangkain nilai-nilai dasar koperasi tersebut, antara lain: koperasi sebagai badan usaha yang menerapkan prinsip efisiensi dan dalam mencari laba tetap memperhatikan kepentingan anggotanya, koperasi sebagai gerakan ekonomi rakyat dalam membina dan mengembangkan aktivitas ekonomi rakyat, dan pengelolaan koperasi berasas kekeluargaan. Lewat nilai-nilai dasar yang terkandung dalam koperasi tersebut, kita dapat memperoleh gambaran tentang koperasi

\footnotetext{
${ }^{17}$ Carunia Mulya, Koperasi Dalam Sistem Perkekonomian Indonesia (Jakarta: Pustaka Obor, 2018), p. 145.

${ }^{18}$ Sugiharsono, Koperasi Indonesia (Jakarta: Direktorat PSMP DEPDIKNAS, 2001), p. 9.
} 
sebagai suatu sistem ekonomi yang berorientasi pada kepentingan publik secara umum.

Dengan berbasis ekonomi rakyat, koperasi tidak dapat dipungkiri memiliki arti yang signifikan dalam upaya menyejahterakan rakyat sekaligus memperkuat fondasi perekonomian nasional. Kegiatan perkoperasian, tidak saja menunjukkan jati diri bangsa Indonesia yang memiliki nilai kebersamaan, tetapi juga sekaligus nilai kegotong royongan dalam memajukan perekonomian masyarakat. Lewat penguatan koperasi berbasis ekonomi kerakyatan, harapan untuk meningkatkan kesejahteraan masyarakat secara berkelanjutan dan berkeadilan dapat dicapai. Apalagi Indonesia memiliki sumber daya sosial ekonomi yang besar dan memadai.

Kontribusi koperasi untuk PDB yang masih rendah harus segera diperbaiki. Perbaikan yang dimaksud, mencakup aspek internal yaitu terkait permodalan, manajemen usaha dan kualiltas SDM, dan juga aspek eksternal yaitu terkait dukungan kemitraan, dukungan kebijakan pemerintah, dan akses pemasaran yang lebih luas serta peraturan pendukung laninya bagi kelangsungan koperasi di Indonesia.

Sangat pentingnya dukungan kebijakan dalam penguatan koperasi lewat perbaikan aspek internal maupun eksternal tersebut bertujuan agar koperasi mampu bersaing dengan lembaga usaha lainnya baik yang bersifat perorangan maupun perusahaan.

Sudah seharusnya pemerintah menunjukkan eksistensinya lewat proteksi dan dukungan jaminan permodalan bagi koperasi, sehingga koperasi mampu mengoptimalkan kontribusinya terhadap pertumbuhan ekonomi nasional. Aspek lain yang tidak kalah pentingnya yaitu dalam penguasaan teknologi dan penguatan SDM. Hal ini dapat dicapai melalui konsistensi pendidikan kewirausahaan perkoperasian dan workshop peningkatan kualitas teknologi informasi.

Agar koperasi dapat maju dan berkembang, pendidikan perkoperasian disertai pelatihan skill penguasaan teknologi tersebut merupakan suatu hal yang penting sekali untuk dilaksanakan. Pendidikan dan pelatihan tersebut akan mencetak para anggota dan pengurus koperasi yang unggul, berwawasan dan berkemampuan tinggi serta memahami secara utuh nilai-nilai dan prinsip-prinsip koperasi. Berbagai upaya 
tersebut bermuara pada tujuan akhir yaitu menjadikan koperasi Indonesia maju dan mampu bersaing dalam dinamika perekonomian global saat ini.

Sebenarnya banyak contoh keberhasilan koperasi di Indonesia, sebut saja contoh keberhasilan koperasi di Provinsi Bali berdasarkan penelitian lapangan yang dilakukan Nidya Waras Sayekti pada tahun 2017 yang ditulis di buku "Koperasi dalam Sistem Perekonomian Indonesia"19. Penelitian tersebut berhasil membuktikan bahwa koperasi di Provinsi Bali mampu menjadi solusi permasalahan ekonomi masyarakat, dan juga berkontribusi penting terhadap pembangunan ekonomi daerah. Melalui koperasi, masyarakat Provinsi Bali mampu secara kolektif menciptakan dan memperoleh keuntungan, kesempatan dan nilai tambah dalam usaha yang lebih besar.

Penguatan kearifan lokal yang dimiliki Provinsi Bali, merupakan faktor penting dalam kemajuan koperasi disana. Apalagi kekhasan dan keunikan budaya lokal menjadikan nilai plus Provinsi Bali sehingga menjadi tujuan wisata utama di Indonesia. Lewat cara tersebutlah koperasi di Provinsi Bali mampu bertahan bahkan memenangkan persaingan dengan kompetitor usaha lainnya yang ada disana.

Kembali ke makna yang terkandung dalam pengertian koperasi sebagai gerakan ekonomi rakyat, pada titik ini koperasi akan mampu menjadi wadah kegiatan ekonomi rakyat dengan mengembangkan kegiatan ekonomi mereka yang pada umumnya merupakan kelompok menengah ke bawah, seperti halnya contoh kemajuan koperasi di Provinsi Bali yang telah benar-benar dikelola secara professional. Apabila contoh keberhasilan koperasi seperti di Provinsi Bali dapat dilaksanakan di seluruh wilayah di Indonesia, niscaya akan meningkatkan pendapatan rakyat kecil dan tingkat kemiskinan rakyat di seluruh penjuru Indonesia secara bertahap akan dapat dikurangi sedikit demi sedikit, sehingga ketidakmerataan pendapatan antara masyarakat kecil dengan masyarakat menengah ke atas akan semakin terkisis secara perlahan.

Setelah koperasi sudah dapat berkembang disetiap wilayah diseluruh Indonesia, dan benar-benar telah mampu membina kegiatan

\footnotetext{
${ }^{19}$ Mulya, p. 147.
} 
ekonomi rakyat, tentu hal ini akan dapat menciptakan lapangan kerja bagi masyarakat, dan pada akhirnya akan mengurangi pengangguran. Apabila semua manajemen kegiatan koperasi yang telah dijelaskan di atas bisa dijalankan dengan baik disertai partisipasi aktif dari masyarakat dan juga perhatian pemerintah lewat kebijakan yang mendukung kemajuan koperasi, maka upaya menghidupkan kembali gagasan ekonomi koperasi sebagai fondasi perekonomian nasional bukanlah sesuatu yang mustahil untuk dapat diniscayakan.

\section{SIMPULAN}

Jika ingin menghidupkan kembali gagasan ekonomi koperasi sebagai fondasi perekonomian nasional, perbaikan manajemen pengelolaan koperasi merupakan sebuah keharusan. Perbaikan yang dimaksud, mencakup aspek internal seperti permodalan, manajemen usaha dan kualiltas SDM, dan juga aspek eksternal yang menyangkut dukungan kemitraan, dukungan kebijakan pemerintah, dan akses pemasaran yang lebih luas serta peraturan pendukung lainnya bagi kelangsungan koperasi di Indonesia.

Lewat contoh suksesnya pengelolaan koperasi di Provinsi Bali seperti yang telah penulis jelaskan dalam bagian pembahasan, koperasi telah mampu mencerminkan ketentuan-ketentuan sebagaimana dalam kehidupan berkeluarga, dimana setiap usaha yang dikerjakan bertujuan untuk kepentingan bersama seluruh anggota keluarga. Hal tersebut sesuai dengan tujuan koperasi yaitu untuk ikut serta membangun tatanan perekonomian nasional dalam rangka mewujudkan masyarakat yang maju, adil, dan makmur berlandaskan Pasal 33 UUD 1945.

Dengan berbasis ekonomi rakyat, koperasi tidak dapat dipungkiri memiliki arti yang signifikan dalam upaya menyejahterakan rakyat. Kegiatan perkoperasian, tidak saja menunjukkan jati diri bangsa Indonesia yang memiliki nilai kebersamaan, tetapi juga sekaligus nilai kegotong royongan dalam memajukan perekonomian masyarakat. Lewat penguatan koperasi berbasis ekonomi kerakyatan, harapan untuk meningkatkan kesejahteraan masyarakat secara berkelanjutan dan berkeadilan dapat 
dicapai. Apalagi Indonesia memiliki sumber daya sosial ekonomi yang besar dan memadai.

Apabila gagasan ekonomi koperasi ini mampu diterapkan secara konsisten dan berkelanjutan, tidak mustahil permasalahan ekonomi yang sampai saat ini masih membelenggu bangsa Indonesia, secara perlahanlahan akan dapat teratasi. Oleh karena itu, sudah menjadi tanggung jawab kita sebagai penerus bangsa untuk menghidupkan kembali gagasan koperasi sebagai fondasi perekonomian nasional. 


\section{DAFTAR PUSTAKA}

Departemen Pendidikan Nasional, Kamus Besar Bahasa Indonesia (Jakarta: Pusat Bahasa, 2008)

Dkk, Moeimam, Kamus Belanda-Indonesia (Jakarta: Gramedia Pustaka Utama, 2008)

Efendi, Rustam, and Boy Syansul Bakhri, 'Konsep Koperasi Bung Hatta Dalam Perspektif Ekonomi Syariah', Al-Hikmah: Jurnal Agama Dan Ilmu Pengetahuan, 15.1 (2018), 111-35

Firdaus, Muhammad, Perkoperasian: Sejarah, Teori Dan Praktek (Bogor: Ghalia Indonesia, 2004)

Hendar, Manajemen Perusahaan Koperasi (Jakarta: Erlangga, 2010)

Jafri, Syafi'I, Fiqih Muamalah (Pekanbaru: Susqa Press, 2002)

Manan, Bagir, Pertumbuhan Dan Perkembangan Konstitusi Suatu Negara (Bandung: Mandar Maju, 1995)

Mulya, Carunia, Koperasi Dalam Sistem Perkekonomian Indonesia (Jakarta: Pustaka Obor, 2018)

Prastowo, Andi, Metode Penelitian Kualitatif (Jakarta: Ar-Ruzz Media, 2016)

Rahardja, Pratama, Pengantar Ilmu Ekonomi (Jakarta: Lembaga Penerbit FE UI, 2008)

Raharjo, Dawam, Koperasi Indonesia Menghadapi Abad Ke-21 (Jakarta: DEKOPIN, 1997)

Sitepu, Camelia Fanny, and Hasyim Hasyim, 'Perkembangan Ekonomi Koperasi Di Indonesia', NIAGAWAN, 7.2 (2018), 59-68

Soeharsono Sagir, Dkk, Kapita Selekta Ekonomi Indonesia (Jakarta: Kencana, 2009)

Soekarno, D, Amandemen Terhadap UUD 1945 (Jakarta: Suara Pembaharuan, 2006)

Sugiharsono, Koperasi Indonesia (Jakarta: Direktorat PSMP DEPDIKNAS, 2001)

Swasono, Sri Edi, Tentang Demokrasi Ekonomi Indonesia (Jakarta: Bappenas, 2008) 